\title{
1 CORINTHIANS 7 IN THE LIGHT OF THE JEWISH GREEK AND ARAMAIC MARRIAGE AND DIVORCE PAPYRI
}

\author{
David Instone-Brewer
}

\begin{abstract}
Summary
The first half of this study explored 1 Corinthians 7 in the light of the Graeco-Roman Greek and Latin marriage and divorce papyri. 1 These papyri showed that much of 1 Corinthians 7 has its basis in Graeco-Roman vocabulary and social structures. The believers at Corinth were facing the problem that divorce under Graeco-Roman law was legally complete when the dowry was returned and the couple separated. Comparisons with Jewish marriage and divorce papyri show that the lifestyle and morals that Paul wishes the Corinthians to adopt are based primarily on the Jewish interpretation of the Old Testament. This is illustrated from both Greek Jewish papyri, which show a Judaism thoroughly embedded in the GraecoRoman world, and Aramaic papyri, which use concepts very closely aligned to Paul's. Ultimately Paul wishes to take them beyond the Jewish models to the teaching of his Lord, and at significant positions Paul is found to stand in contrast to all the contemporary marriage and divorce papyri.
\end{abstract}

\section{Jewish Greek Marriage and Divorce Papyri}

Jews in first and second century Egypt and Palestine used both the Greek and Aramaic languages for their marriage contracts and divorce deeds. The form of words was determined by the language employed, so that the Greek versions are very similar to those found in the rest of the Graeco-Roman world. The only Greek Jewish divorce deed we have is JD-13 from Alexandria, which has almost exactly the same

\footnotetext{
1 ' 1 Corinthians 7 in the Light of the Graeco-Roman Marriage and Divorce Papyri', TynB 52.1 (2001) 101-116.
} 
wording as GD-132 but with different names, so it will not be cited here. JM128 is one of the five Jewish Greek marriage certificates which have survived. They are all from early second century Palestine and are similar to each other, being Greek in style but with some Jewish features.

\title{
Marriage Contract, AD 128, Petra (JM128 i.e. P.Yadin. 18):
}

\begin{abstract}
[Date, Place], WF ${ }^{4}$ gave over $\mathrm{W}$, his very own daughter, a virgin, to $\mathrm{H}$, for $\mathrm{W}$ at be a wedded wife to $\mathrm{H}$ for the partnership of marriage according to the laws, she bringing to him on account of bridal gift feminine adornment in silver and gold and clothing appraised by mutual agreement as they both say, to be worth 200 denarii of silver, which appraised value $\mathrm{H}$ acknowledged that he has received from her by hand forthwith from WF and that he owes to $W$ together with another 300 denarii which he promised to give to her in addition to the sum of her aforesaid bridal gift ( $\pi \rho 0 \sigma \phi \circ \rho \alpha$ ), all accounted toward her dowry, pursuant to his undertaking of feeding and clothing both her and the children to come in accordance with Greek law ( $\dot{\varepsilon} \lambda \lambda \eta v \kappa \hat{\varphi}$ vó $\mu \omega)$ upon H's good faith $(\pi i \sigma \tau \varepsilon \omega \varsigma)$ and in peril and the security of all his possessions, both those which he now possesses in his said home village and here and all those which he may in addition validly acquire everywhere, in whatever manner $\mathrm{W}$ may choose, or whoever acts through her or for her may choose, to carry out the execution. $\mathrm{H}$ shall redeem this contract for W whenever she may demand it ( $\dot{\alpha} \pi \alpha \imath \tau \dot{\sigma} \sigma[\varepsilon 1])$ of him, in silver secured in due form, at his own expense interposing no objection. If not, he shall pay to her all the aforesaid denarii twofold, she having the right of execution, both from $\mathrm{H}$ and upon the possessions validly his, in whatever manner WW or whoever acts through her or for her may choose to carry out the execution. In good faith ( $\pi i \sigma \tau \varepsilon l$ ) the formal question was asked and it was acknowledged in reply that this is thus rightly done.
\end{abstract}

\footnotetext{
2 This certificate is cited in the previous paper. The form of references used here are those used in my collection of Greek, Aramaic, and Latin marriage and divorce papyri at http://www.tyndale.cam.ac.uk/Brewer/marriagepapyri/. The first letter indicates the language/culture and the second letter indicates the type of document. The language/cultures are A for Aramaic, $L$ for Latin, J for Jewish Greek and $G$ for Graeco-Roman Greek. The types of document are $M$ for Marriage contract, D for divorce certificate, and $\mathrm{R}$ for Related legal texts. The numbers indicate the date, with a negative number for BC. Therefore GD-13 is a Graeco-Roman Greek Divorce papyrus from $13 \mathrm{BC}$. It is also known as $B G U 1103$.

3 Translation based on Naphtali Lewis, Yigael Yadin, and Jonas C. Greenfield, eds., The Documents from the Bar Kokhba Period in the Cave of Letters: Greek Papyri (Jerusalem: Israel Exploration Society: Hebrew University of Jerusalem: Shrine of the Book, 1989), 80.

${ }^{4}$ Specific names have been replaced by $\mathrm{W}$ (for wife or bride), $\mathrm{H}$ (for husband or groom), WM, WF, and WB (for wife's mother, father, and brother) to help the reader understand relationships which might be obscured when using the names. Details such as lists of property, dates, and locations, have been summarised by words in square brackets. The full texts in Greek and Aramaic are available at http://www.tyndale.cam.ac.uk/Brewer/marriagepapyri/.
} 
I, WF, have given my daughter $\mathrm{W}$, a virgin, in marriage to $\mathrm{H}$, according to what is written above. WF wrote it.

I, $\mathrm{H}$, acknowledge the debt of silver denarii, 500, the dowry of $\mathrm{W}$ according to what they wrote above. $\mathrm{H}$ wrote it.

I [name of scribe] wrote this.

[Witness signatures].

This contract shows typically Greek features, but with a great number of Jewish elements. Greek features including the right of the woman to demand her dowry back and leave whenever she wishes with a financial penalty if the payment is not made promptly, and the promise to 'feed and clothe'.

The Jewish features are seen mainly in the financial arrangements, especially in the reference to a 'bride gift' which is presumably the bride price which Jewish grooms normally paid. In early rabbinic Judaism this was set at 200 denarii for a virgin and 100 for a divorcee or widow, ${ }^{5}$ though this was often increased. This payment by the groom was theoretical, to be supplied only if there was a divorce, whereas the dowry by the bride's family was 'received from her by hand'. This shows how important the dowry had become in Jewish circles, even though it was unknown in OT law. Bickerman showed that the LXX changed some texts to suggest that the marriage payment came from the bride, ${ }^{6}$ so a bridal dowry had already become normal Jewish practice by the second century BC.

Another possible Jewish feature is the stipulation that the whole of his property is security for his obligation to support her. This was typical in Demotic contracts ${ }^{7}$ and Jewish Aramaic contracts, though it was not unknown for a Greek contract. ${ }^{8}$ Early Jewish traditions say

\footnotetext{
${ }^{5}$ mKet. 1:2.

6 E.g. Gen. 34:12; Ex. 22:15-16. He also points out a first century saying in Mishnah that a groom would not marry till the bride's family paid a dowry - see E.J. Bickerman, 'Two Legal Interpretations of the Septuagint' in Studies in Jewish and Christian History, Arbeiten zur Geschichte des antiken Judentums und des Urchristentums; Bd. 9, pt. 1-3 (Leiden: E.J. Brill, 1976-1986), vol. I. 201-224, esp. pp. 209-211.

7 See Pieter Willem Pestman, Marriage and Matrimonial Property in Ancient Egypt: A Contribution to Establishing the Legal Position of the Woman, Papyrologica Lugduno-Batava v. 9 (Leiden: E.J. Brill, 1961), 115-42. Geller thinks that Simeon may have been influenced by the Demotic contracts-M.J. Geller, 'New Sources for the Origins of the Rabbinic Ketubah', Hebrew Union College Annual 49 (1978) 227-45.

8 As seen in GM66 in the previous paper. Llewelyn suggests that upper class Egyptians adopted the typical Greek contract while lower class Egyptians continued with the Demotic form, even when their contract was written in Greek. See S.R. Llewelyn, ed., New Documents Illustrating Early Christianity, vol. 6
} 
that this stipulation was introduced as part of the reform of marriage law by Simeon ben Shetah. ${ }^{9}$ Some modern scholars have suggested that this is a mythical history which was reconstructed to make a link between the Old Testament mohar gift from the groom and the Graeco-Roman dowry from the bride's family. ${ }^{10}$ Normally in Greek contracts the husband supports his wife 'in proportion to his means'

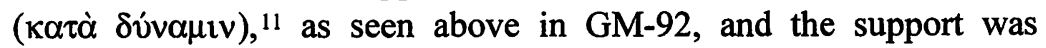
underwritten only by the value of the dowry. This limited her legal claim on him in the courts. In this contract there is a reference to both systems, stating that the dowry is supplied 'pursuant to his undertaking of feeding and clothing' but it also states that 'all his possessions' are security for this duty.

The phrase 'food and clothing' is also likely to be influenced by a Jewish background, because it is also found in all other surviving Jewish Greek certificates. Although the obligation to clothe is relatively common in Greek contracts, 12 as seen above in GM-92, the inclusion of 'feeding' is normal only in Demotic contracts. ${ }^{13}$ In Greek contracts it was much more common to refer to the 'necessaries'

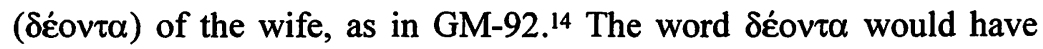

(North Ryde: The Ancient History Documentary Research Centre, Macquarie University, 1992), 8.

9 tKet. 12:1; bKet. 82b; yKet. 8:11, 32b. See the analysis in Leone J. Archer, Her Price Is Beyond Rubies: The Jewish Woman in Greco-Roman Palestine (JSOTSup 60, Sheffield: Sheffield Academic Press, 1990), 159-66 and Menachem Elon, Jewish Law: History, Sources, Principles, 4 vols. (Philadelphia: Jewish Publication Society, 1994), 559-60. The same progression of custom which is traced by the rabbis is found in Egyptian contracts from about $230 \mathrm{BC}$ - see Llewelyn, New Documents, vol. 6, 13; M.J. Geller, 'New Sources for the Origins of the Rabbinic Ketubah', Hebrew Union College Annual 49 (1978) 227-45.

${ }^{10}$ E.J. Bickerman, 'Two Legal Interpretations of the Septuagint', 212-15; Michael Satlow, 'Reconsidering the Rabbinic Ketubah Payment' in The Jewish Family in Antiquity, ed. Shaye J.D. Cohen (Atlanta: Scholars, 1993), 133-51. But (as Satlow notes in pp. 144-48) very similar practices are found in the Ancient Near Eastern law code of Hammurabi (\#\#137-40) and in Elephantine marriage contracts of the 5th C BC. In both, there is a payment which is forfeited if divorced. These fell into disuse in Roman times, and Yavneh resurrected them as ketuva payments.

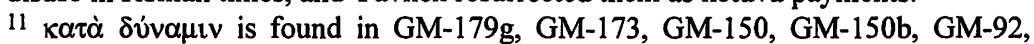
GM-13b, GM-10, GM-10b, GM-10c, GM81, GM94, GM110, GM127, GM136, GM143, GM149, GM150, GM150e, GM150f, GM150s, GM154, GM162, GM170, GM170c, GM190, GM201, GM223, GM260, GR157.

12 Other examples of 'clothing' without 'feeding' in Greek contracts include GM92, GM-13b, GM-10b, GM143.

13 E.g. GM21 (which is a Greek translation of a Demotic contract), P.Ryl.Dem. 10

$14 \mathrm{GM}-92$ is analysed in my previous paper on Graeco-Roman marriage contracts. In that paper I suggested that it was linked to Paul's description of a husband who was 'bound' ( $\delta \varepsilon \delta \varepsilon \sigma \alpha l)$ to a wife (v. 27), but Dr K.L. McKay has pointed out to me in a private communication that $\delta \varepsilon \delta \delta \varepsilon \sigma \mathrm{l}$ is from $\delta \varepsilon \dot{\omega} \omega$ 'I bind' (root dey-) and 
been an eminently suitable term for Jewish marriage certificates because it occurred in the LXX translation of Exodus 21:10 along with 'clothing', just as it does in many Greek contracts. 15 Therefore there must have been a very good reason why all Greek Jewish contracts use the rare phrase 'food and clothing' instead. The most likely reason is the influence of Exodus 21:10-11 which, along with Deuteronomy $24: 1-4$, was the basis of Jewish divorce legislation, as detailed below.

The binding nature of the contract is emphasised in a way not found in any other Graeco-Roman document. The contract establishes its binding nature both in Greek law and in the personal trustworthiness of the groom. The reference to 'Greek law'16 might appear to be a Greek trait, but it is actually a Graeco-Roman version of a thoroughly Jewish phrase, which appears in almost every known Jewish Aramaic and Hebrew marriage contract: 'in accordance with the Laws (כדין) of Moses and Israel'.17 This is linked with the personal trustworthiness of the groom: in the phrase: 'in accordance

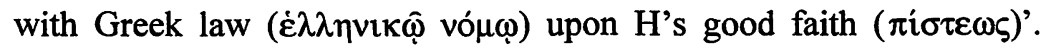
Although this use of $\pi i \sigma \tau \iota \varsigma$ is normal in Greek contracts of loan or sale, as an indication of personal good faith or guarantee, it is not found in any Graeco-Roman marriage certificates except in those of

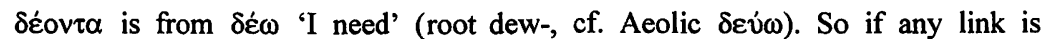

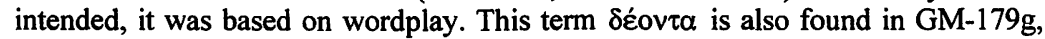
GM-173, GM-150, GM-150b, GM-25, GM-13, GM-13b, GM-10, GM81, GM110, GM127, GM136, GM143, GM149, GM150, GM150e, GM151b, GM154, GM170, GM170c, GM190, GM200c, GM201, GM223, GM260, GM363, GD200, GR157, GR250.

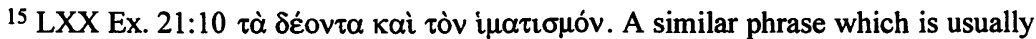

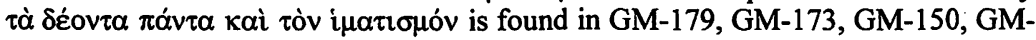
150, GM-150b, GM-92, GM-25, GM-13, GM-13b, GM-10, GM81, GM110 (reconstructed), GM136, GM143, GM149, GM150, GM151b, GM154, GM170, GM190, GM200c, GM223, GM363, GR-55.

16 This is translated 'Greek custom' by Lewis and others since his edition. However, this obscures the clear link with the wording in Aramaic contracts.

17 Some early versions have 'laws of Moses and the Judaeans' (AM126, and possibly AM1 17). JM131 has 'according to Greek laws and manners'. This is seen

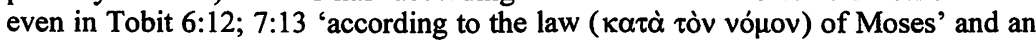
Edomite marriage contract of the 2nd century BC, AM-176, 'in accordance with the customs (כנומוס) of the daughters of Edom'. Cotton and Yadin suggest that the reading in JR-218 'according to the civic [laws] of the [Je]ws to have me as wi[fe]' may also be related - see her discussion in Hannah M. Cotton and Ada Yardeni, Aramaic, Hebrew and Greek Documentary Texts from Nahal Hever and Other Sites: with an Appendix Containing Alleged Qumran Texts (DJD 27; Oxford: Clarendon, 1997), 225; Yigael Yadin, Jonas C. Greenfield, and Ada Yardeni, 'Babatha's Ketubba', IEJ 44 (1994) 75-101. 
Jews. ${ }^{18}$ In fact this combination of a reference to binding obligations under public law (vó $\mu \varsigma \zeta$ ) and personal faithfulness ( $\pi i \sigma \tau \iota \varsigma$ ) is not found in any other Graeco-Roman legal document.

This emphasis on the legally binding nature of the maintenance element in the marriage contract, was completely foreign to GraecoRoman marriage contracts. Although Graeco-Roman contacts had the force of law behind them, there was little emphasis on any legal obligations other than the return of the dowry. There were sometimes a list of stipulations, but these were simply linked with the procedure for ending the contract if these stipulations were broken. In Greek contracts there was almost an expectation that the marriage would end in divorce rather than death. In Jewish contracts, especially Aramaic and Hebrew ones, there is an expectation that the marriage will end in death (as seen below).

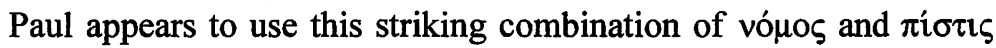
in Greek Jewish marriage contracts in Romans 7:2, where he chooses a marriage contract as an illustration of the relationship between salvation by law or by faith. He pictures the Jewish believer as married to the Law, and wishing to be married to Christ instead. Barring a divorce (which presumably the Law will not provoke or initiate) the only way to end the contract is through death. Therefore Christ's death, which the believer shares in, becomes the means by which a Jewish believer can end the old covenant of law and start the new covenant of faith.

\section{Jewish Aramaic Marriage and Divorce Papyri}

Palestinian Jews in the first two centuries used both the Greek and Aramaic languages in their marriage documentation. It is unclear what made them chose one or the other, because both appeared to have equal standing. The most likely reason for using a Greek form of contract is greater legal respectability and perhaps enforceability. ${ }^{19}$

18 Of the five which have survived (one very fragmentary), it is found in this one and JM131. The word $\pi i \sigma \tau 1 \varsigma$ is used in a very late marriage certificate (GM570) though not in this way. It also occurs in some divorce certificates (GD204, GD254) as 'agree in good faith' and as 'a security' respectively, and also in a couple of marriage related legal petitions (GR186, GR250b).

${ }^{19}$ Cotton concludes 'The use of Greek in my opinion is to be explained by the desire to make the deed of gift valid and enforceable in a Greek-speaking court, such as that of the governor of the province.' She points out that some Greek marriage contracts have very poor Greek, and read as though they were woodenly translated from Aramaic. See Hannah M. Cotton, 'The Rabbis and the Documents' 
The Aramaic contract written out below is a marriage of Judah to his second wife Babatha, ${ }^{20}$ and the Greek Jewish contract above (JM128) is that of Judah's daughter, just two years later. Presumably Judah decided to use Aramaic for his own marriage and yet was willing to be party to a Greek contract with his son-in-law. The main reason for avoiding a Greek contract was probably because Judah was already married. Polygamy was still practised by Palestinian Jews, but it was not practised in any Graeco-Roman culture. ${ }^{21}$ The Aramaic contracts follow fairly closely the rabbinic norms as recorded in Mishnah, though there was still a great deal of flexibility in the wording.

\section{Marriage Contract, AD 126, Palestine (AM126 i.e. P.Yad. 10): 22}

[Date][Place \& names missing]... that you will be my wife according to the law of Moses and the Judeans and I will feed you and clothe you and I will bring you (into my house) by means of your ketubah and I owe you the sum of 400 denarii ... together with the due amount of your food and your clothes and your bed, provision fitting for a free woman. [Some accidental duplication.] And if you are taken captive, I will redeem you, from my house and from my estate, and I will take you back as my wife, and I owe you your ketubah money... And if I go to my eternal home before you, male children which you will have by me will inherit your ketubah money, beyond their share with their brothers, female children shall dwell and be provided for from my house and from my estate until the time when they will be married. And if I go to my eternal home before you, you will dwell in my house and be provided for from my house and from my estate until the time that my heirs wish to give you your ketubah money. And whenever you tell me I will replace this document as is proper. [Signatures]

The wording of this and other similar contracts has been the subject of numerous studies..$^{23}$ The resemblances to Greek contracts include the overall structure (Name, Place, Dowry, Stipulations, Signatures), the

in Jews in a Graeco-Roman World ed. Martin Goodman (Oxford \& New York: OUP, 1998), 167-79.

${ }^{20}$ For the family details and other documents of this family see Lewis, Documents from the Bar Kokhba Period, esp. pp. 22-25.

21 For details about polygamy see my 'Jesus' Old Testament Basis for Monogamy', in The Old Testament in the New Testament: Essays in Honour of J.L. North ed. Steve Moyise, JNTS Supp 189 (Sheffield: Sheffield Academic Press, 2000). Egyptians were said, by Diodoros to be polygamous, but their marriage papyri show that they were not-Pestman, Marriage and Matrimonial Property, 3.

22 Translation based on Yadin 'Babatha's Ketubba'. This text is not published in any of the collections, so it is often overlooked.

${ }^{23}$ R. de-Vaux, J.T. Milik, \& P. Benoit, Les grottes de Muraba at (DJD 2; Oxford: Clarendon, 1961) 109-117; Archer, Her Price Is Beyond Rubies; Cotton, Aramaic, Hebrew and Greek Documentary Texts from Nahal Hever; Lewis, Documents from the Bar Kokhba Period; Cotton, 'A Cancelled Marriage Contract'. 
dowry given by the wife's family (called the ketubah), and the obligation of material support for the wife. There are some resemblances to Demotic type Greek contracts, including the reference to food and clothing and the underwriting of the husband's whole estate to provide support for the wife (as detailed above). As in all Jewish Aramaic and Hebrew contracts, the main financial transaction is a gift from the groom, not from the bride's family. ${ }^{24}$ The Jewish nature of the contract is seen also in the phraseology. The phrase 'you will be my wife according to the law of Moses and the Judeans' is found, with some small variations, in almost all Jewish Aramaic and Hebrew contracts (as footnoted above).

The phrase 'feed and clothe' is also very common in Jewish marriage contracts (as detailed above), and is often accompanied, as here, by some kind of euphemistic reference to conjugal rights. Here we find two references to food and clothing with each followed by a different euphemistic phrase: 'I will bring you into my house' and 'your bed'. ${ }^{25}$ This threefold group is based on the threefold marriage obligations in Exodus 21:10-11, to provide food, clothing, and love. ${ }^{26}$ These obligations, together with Deuteronomy 24:1-4, formed the basis for rabbinic divorce law. Men and women had the right to a divorce if any of these obligations were not carried out, and the guilty party lost the dowry. ${ }^{27}$ In theory only men could write a divorce certificate, and women had to demand a certificate through a rabbinic court, but in practice women may have taken the law into their own hands and asked a scribe or a male guardian to write it out. ${ }^{28}$

Paul recognises these same marital obligations in 1 Corinthians 7.29 In verses $3-5$ he refers to conjugal rights as a moral obligation within

24 Cotton regards this as one of the most important distinguishing features-Cotton, 'A Cancelled Marriage Contract', 82-84.

25 The translation of this latter term is debatable, but is likely to be correct. Yadin says the word פרש may be פרס 'to spread out, cover' which is euphemistic for conjugal relations, or it may be a loan word from Arabic fařs, 'bed' which is also a euphemism-Yadin 'Babatha's Ketubba', 88-89.

26 Paul Shalom, 'Exod. 21:10, A Threefold Maintenance Clause', JNES 29 (1969), 48-53, repeated in his Studies in the Book of the Covenant in the Light of Cuneiform and Biblical Law (SVT 17, Leiden: E.J. Brill, 1970), 52-61.

27 The obligations for food and clothing are listed in mKet. 5:5, 8, and the obligation of love is defined in mKet. 5:6-7.

${ }^{28}$ AD135 appears to be a divorce certificate written out on behalf of a woman and addressed to her husband. See D. Instone Brewer, 'Jewish Women Divorcing Their Husbands in Early Judaism: The Background to Papyrus Se'elim 13', HTR 92 (1999) 349-57.

${ }^{29}$ This reference to Ex. 21:10-11 in 1 Cor. 7:3-5 has not been widely recognised. It is noted in the excellent reference system prepared for the Revised Version 
marriage. ${ }^{30} \mathrm{He}$ allows brief periods of abstinence (which the rabbis also allowed ${ }^{31}$ ) but he did not allow celibate marriages, which some at Corinth appear to have wanted. Paul also recognised the material obligations of food and clothing in verses 32-34, though he does not name them as two separate items. This classification of the three obligations into two groups, material support and what we might call emotional support, mirrors the way in which first century rabbinic traditions dealt with these obligations. The penalty for material neglect was the normal divorce and loss of the dowry, but emotional neglect was punished by a gradual transfer of the dowry to the injured partner, in the hope that the guilty partner would relent. ${ }^{32}$ This difference may have been influenced by the Graeco-Roman world which punished material neglect by loss of the dowry, but did not regard emotional neglect as punishable.

The Aramaic contracts, like the Graeco-Roman contracts, only mention the material support which the husband has to give to his wife, though Rabbinic case law demonstrates that they applied these obligations to both husband and wife. The husband provided the food

(Cambridge: CUP, 1912) and in a few publications including: R.J. Rushdoony, The Institutes of Biblical Law (Philadelphia: Presbyterian \& Reformed, 1973) 403; William F. Luck, Divorce and Remarriage: Recovering the Biblical View (San Francisco: Harper and Row, 1987), 34-35; Otto A. Piper, The Biblical View of Sex and Marriage (London: James Nisbit \& Co Ltd, 1960), 31-32; Brian S. Rosner, Paul, Scripture and Ethics: A Study of 1 Corithians 5-7 (Arbeiten zur Geschichte des antiken Judentums und des Urchristentums 22; Leiden: E.J. Brill, 1994), 159; Peter J. Tomson, 'Paul and the Jewish Law: Halakha in the Letters of the Apostle to the Gentiles', Compendia Rerum Iudaicarum ad Novum Testamentum III:1 (Minneapolis: Fortress, 1990), 107; Daube, NT \& Rabbinic Judaism, 365. The connection was shown convincingly more than a century ago in N. Herz, 'A Hebrew Word in Greek Disguise: 1 Cor. vii.3', Expository Times 7 (1895) 48. He

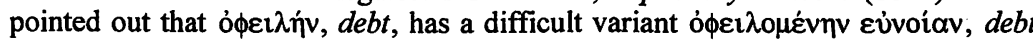
of goodwill. This phrase never occurs in the sense of conjugal rights and he suggested that $\varepsilon \dot{v} v o r \alpha v$ may be a transliteration of the word interpreted by the rabbis as conjugal rights in Ex. 21:10, ענתה. He noted that such transliteration occurs often in LXX proper names or doubtful words, e.g. $1 \mathrm{Chr} .4: 22$. However, it is also possible that debt of goodwill is one of the 'ascetic' glosses which are found throughout this chapter.

${ }^{30}$ Fee points out that the language is very strong. Not only does Paul talk about conjugal activity as ó $\phi \varepsilon \imath \lambda \dot{\eta}$, a debt (v. 3) but also says that withholding it is á $\pi 0 \sigma \tau \varepsilon \rho \varepsilon \omega$, to defraud or steal (v. 5-cf. the same word at 6:7)-Gordon D. Fee, The First Epistle to the Corintians (Grand Rapids, Mich.: Eerdmans, 1987) ad loc. Paul is probably thinking of the Hebrew מעל which has the dual meaning of 'monetary fraud' and 'sexual unfaithfulness'-see Jastrow, who refers to Sifré Num. 7 'Does She defrauded him refer to marital betrayal or money matters?'

31 The Houses of Hillel and Shammai disagreed about the length of abstinence which was allowed-see mKet. 5:6.

32 mKet. 5:7. 
and yarn, while the wife cooked and weaved. They even define the amount of money the husband had to spend and the jobs which the woman had to carry out in the house. ${ }^{33}$ The absence of the bride's obligations may reflect the influence of Greek contracts, or perhaps it was omitted because her obligations did not relate to finances and the dowry in the same way as the husband's.

Paul refers to both women and men whenever he discusses the marriage obligations. In fact he is so conscientious in making balanced statements, that he often repeats whole phrases in order to emphasise this. ${ }^{34}$ This emphasis of equal responsibilities in marriage is presumably influenced by his Jewish background, though he does not speak about any prescribed amounts of money or work in the way that rabbinic traditions do.

The most startling difference between Aramaic marriage contracts and Greek Jewish and non-Jewish contracts is the assumption about how the marriage will end. The Greek contracts specify what will happen in the event of divorce, while the Aramaic contracts specify what will happen in the event of death. This difference is not absolute-many Greek contracts speak about post-mortem arrangements and some Aramaic contracts make mention of divorce. ${ }^{35}$ But the overwhelming concern in Greek contracts is with divorce, while Aramaic contracts are more concerned with death.

The promise to the widow in this marriage contract is that she may live in the marital home and be provided for from the estate 'until the time that my heirs wish to give you your ketubah money'. This is different from other Aramaic marriage contracts, which allow the widow to remain as long as she wishes. ${ }^{36}$ According to Yadin, this

33 mKet. 5:5, 8 .

${ }^{34}$ See 1 Cor. 7:3: 'The husband should give to his wife her conjugal rights, and likewise the wife to her husband'; v. 4: 'For the wife does not rule over her own body, but the husband does; likewise the husband does not rule over his own body, but the wife does'; vv. 32-34 'The unmarried man is anxious about the affairs of the Lord, how to please the Lord; but the married man is anxious about worldly affairs, how to please his wife' and then almost exactly the same for the wife.

35 Only one among the 5 which have survived from the first two centuries-AM125 '[...I]f I di[vorce you..] I will return [to you the money of] your [ke]tubba and everything that is [yours that is with] me. And if [there be] child[ren (daughters) by me] According to the law, th[ey a]re to live [in] my house and [be] nourished fr[om my possessions... until]'. It is possible that this type of stipulation is also in AM117 which is fragmentary at this point.

36 E.g. AM125: 'I]f I go to that hou[se] be[fore you, you are to dwell] and be nourished [from my possession] all the days in the house o[f our son]s, the house of your widow[hood until] your death [and] your [keth]ubah ... is yours [...]'. AM117 is similar, though fragmentary, and the others are too fragmentary to 
contract is an example of the Judaean contract which is reflected in later rabbinic traditions and the others are examples of the Jerusalem and Galilean contract which is reflected in Mishnah. ${ }^{37}$

The assumption that marriage continues till death, which is seen in Aramaic Jewish contracts, may represent the situation from a previous century, before the reforms of Hillel made divorce much easier. Marriage contracts are, by their nature, conservative in their wording, and slow to change with the shifting needs of society.

Hillel, in the first century BC, allowed men to divorce their wives on the ground called 'any matter'. Before this we must assume that men, like women, could only gain a divorce if their partner had been unfaithful or had failed in one of the three obligations. This would make divorce difficult and rare. Hillel's new ruling effectively gave men the same rights of divorce in Jewish law as they had in Greek law. They could, at any time and for any reason, return the dowry and dismiss their wife. The only additional requirement was to write out a divorce contract and give it to their wife. Jewish women did not share this right and could only get a divorce if they could prove their husband had failed in his obligations. Hillel derived his teaching exegetically from the phrase 'a matter of indecency' (ערות דבר) in Deuteronomy 24:1 which he read as two grounds for divorce: 'indecency' and 'a matter'.

The Shammaites and Jesus had a different interpretation They both argued that the only ground for divorce in this verse was 'a matter of indecency' ${ }^{38}$ The Shammaite view in this debate is abbreviated in a similar way to Jesus teaching: 'A man should not divorce his wife except if he found indecency in her. ${ }^{39}$ This appears to suggest that Shammaites only allowed divorce for the one ground of indecency, but we know that they also allowed divorces based on the other three

decide. There is nothing about this right in Jewish Greek contracts, except an unusual form in JM125: 'If $\mathrm{H}$ dies before W, W will be nourished and clothed from the fortune of $\mathrm{H}$ all the time that she wishes to remain a widow [...] But if she wishes to leave after his death, or if she sends in her place [... she will recover the ketubah of] 2000 denars.'

37 mKet. 4:12. See Yadin, 'Babatha's Ketubba', 94.

38 Mt. 19:3-9. My understanding of these passages is as follows: Jesus was asked 'Can a person be divorced for "any matter"?' He replied, like the Shammaites, 'No, only for "a matter of indecency"' and added that if someone was divorced for 'any matter' they were not properly divorced, so if they remarried they were committing adultery. For more details see my 'Jesus' OT Basis for Monogamy'.

${ }^{39}$ ySot. 1:2, $16 b$. 
grounds derived from Exodus 21:10-11.40 There is no extant record of any part of Jewish society which did not accept these other three grounds. Jesus was silent on Exodus 21:10-11, perhaps because he was not asked about it or, more probably, because he agreed with the standard teaching which was followed by all branches of Judaism. He did not, after all, leave any teachings about monotheism or celibacy outside marriage, presumably because here too he agreed with the teaching shared by all other Jews on these subjects.

Paul rejected both the Greek right to divorce by simple separation, and Hillel's divorce for 'any matter'. In 1 Corinthians 7 he is mainly addressing the rights within Graeco-Roman law, because he assumes that the woman, as well as the man, can break up the marriage by simply walking out. Paul taught that a Christian should not walk out on or dismiss their partner (vv. 10-11) even if their partner is not a Christian (vv. 12-14). He bases the first half of this on the teaching of 'the Lord', by which he presumably refers to a Gospel tradition, but he says that verses $12-14$ is not based on a similar tradition ('I say, not the Lord').

What is the teaching which Paul cannot derive from the Gospels? There is little difference between the teaching of verses $10-11$ and verses 12-14-both state that one should not break up a marriage. The difference lies in the people whom he addresses. In verses 10-11 he addresses a pair of married believers and in verses 12-14 he addresses one believer in a mixed marriage. Paul justifies his conclusions in verses 12-14 with a lengthy argument about the possibility that the Christian may convert the non-believer, and says that, in any case, the children are sanctified by having just one Christian parent. It appears that Paul did not feel that the Gospel traditions addressed the issue of whether a believer should remain in a mixed marriage or not, and feels that he has to justify the conclusions which he has reached.

In verse 15 Paul has to face the fact that a believer married to a pagan may not be able to hold the marriage together. Their partner may simply walk out. However, in the case of two Christians, Paul advised the separated partners to remain single in the expectation of reconciliation (v. 10). The church could, by disciplining them if necessary, bring them back together eventually. But in the case of a

40 mKet. 5:6 records a debate with the Hillelites about the length of time a man was allowed to withhold conjugal rights before he could be taken to court and sued for divorce. From this is it clear that they accepted one ground based on Ex. 21:10-11, so presumably they also accepted the other two. 
non-believer walking out, there is little that the believer can do, so Paul says they are 'no longer bound' (v. 15, $\delta \varepsilon \delta o v i \lambda \omega \tau \alpha \mathrm{l}$ ). This is the most contentious phrase in the chapter with regard to Paul's theology of remarriage. Does it mean that they are no longer bound to live with the partner, or no longer bound by the marriage? ${ }^{41}$ And if it means the latter, does this give them freedom to remarry? The language is

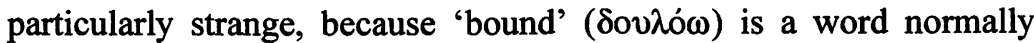
reserved for situations of slavery. The key to this difficult word is found in the Jewish divorce certificates.

\section{Divorce Deed, $A D$ 72, Masada (AD72 i.e. DJD II. $19=$ P.Mur. 19):42}

[Date, Place] I H divorce and release of my own free will, today you W who had been my wife before this time. You are free on your part to go and become the wife of any Jewish man that you wish. This is for you a writ of release and a bill of divorce, [illegible portion]. ${ }^{43}$ And all ruined and damaged [...] to you will be restored and I will pay fourfold.' And at any time that you ask me, I will replace for you this document, as is proper. [Signature of $\mathrm{H}$ ]

We can be fairly certain that this is the wording of Aramaic divorce certificates in Paul's day. The date of this certificate is verified by the annihilation of the Jewish inhabitants of Masada in AD 74, and the wording is confirmed by an early Aramaic tradition in Mishnah. ${ }^{44}$

In 1 Corinthians 7:39 Paul cites from the standard Jewish divorce contract: 'She is free to be married to whomever she wishes, only in the Lord.' A similar phrase occurs in many Graeco-Roman divorce

\footnotetext{
${ }^{41}$ Some other possibilities have been suggested, e.g. 'not under bondage to deny his or her faith in order to avoid a broken home'-Theodore H. Epp, Marriage, Divorce \& Remarriage (Good News Broadcasting Assoc., Bawtry, Doncaster. 1954-91), 25-26; not bound to keep marriage vows, but still bound to remain married-Andrew Cornes, Divorce and Remarriage: Biblical Principles and Pastoral Practice (London: Hodder \& Stoughton, 1993), 251; not subject to imprisonment, which would happen if they tried to prevent their spouse leaving-R.L. Roberts, 'The Meaning of Chorizo and Douloo in I Corinthians 7:10-17', Restoration Quarterly 8 (1965) 179-84, p. 183.

42 Translation based on Roland de-Vaux, Discoveries in the Judaean Desert, II, 104-109 and Archer, Her Price Is Beyond Rubies, 298-99, as amended by Yadin, 'Babatha's Ketubba', 86, and in 'Expedition D-the Cave of the Letters', IEJ 12 (1962) 227-57, p. 249, and by Tal Ilan in 'Notes and Observations on a Newly Published Divorce Bill from the Judean Desert', HTR 89 (1996) 195-202, pp. 198-99.

43 Ilan restores this in a similar way to Archer, as 'For this I will give back [....]' but Yadin thinks that it is the traditional phrase 'according to the law of Moses and Judaeans' (בדין [משה] ויהודאי).

${ }^{44}$ mGit. 9:3.
} 
certificates, ${ }^{45}$ but the Jewish certificate puts a religious limit on whom she may marry. In the Jewish certificate she may only marry a Jew, and in the Christian version she may only marry 'in the Lord'. ${ }^{46}$

Paul cites the divorce certificate, but with reference to the rights of widows. In the Graeco-Roman world a widow could marry whomever she wished, so there was no need to state this. Commentators are probably correct in concluding that Paul wants to deny the obligation of a childless Jewish widow to marry her brother-in-law in levirate marriage in order to produce an heir. ${ }^{47}$ Paul is asserting that a widow can marry (or not marry) whomever she wishes, just as a divorcee can. Precisely the same reasoning was later used for the same purpose in rabbinic debates. ${ }^{48}$ This right is already seen in one second century Jewish Greek Marriage contract which implies that the widow can choose whether or not to marry, which effectively frees her from a levirate marriage..$^{49} \mathrm{It}$ is ironic that the original purpose of a divorce certificate was to give a divorcee the same legal rights for remarriage as a widow ${ }^{50}$ and now Paul cites a divorcee's rights in order to defend the rights of widows.

The divorce deed is compared to an emancipation certificate for a slave by early rabbinic traditions. ${ }^{51}$ This was not because they regarded marriage as slavery, ${ }^{52}$ but the divorce legislation of Exodus

${ }^{45}$ E.g. GD-13 in the previous paper, and other discussed there.

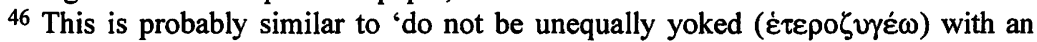
unbeliever' ( 2 Cor. 6:14). Although 2 Cor. 6 may refer to more general business

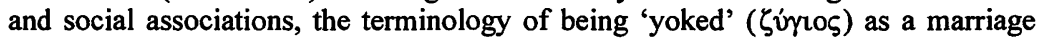

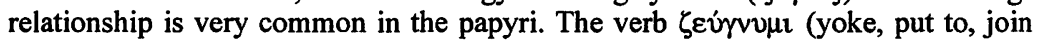

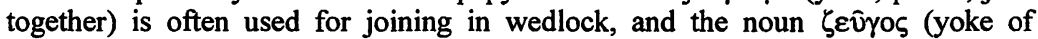
beasts, pair) often refers to a married couple. Some related words are also used for

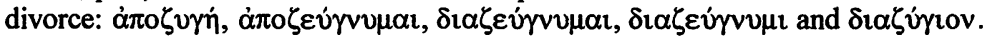

47 E.g. Barrett, First Epistle to the Corinthians, 186; Fee First Epistle to the Corinthians, 356.

48 bKid. 13b, R.Ashi [d. AD 427] 'just as divorce completely frees her, so does death completely free [the widow].' This parallel is normally overlooked, probably because it is late, but it is likely that this argument dates back to the first century when the movement to allow women freedom from levirate marriages started, as evidenced by the House debate in mYeb. 13:1. Josephus uses similar language when he says that a released levirate widow 'shall be free to marry any suitor whom she will' (Jos. Ant. 4:255-56).

$49 \mathrm{JM} 125$ ' $\mathrm{W}$ will be nourished... all the time that she wishes to remain a widow'.

50 See my 'Deuteronomy 24:1-4 and the Origin of the Jewish Divorce Certificate', JJS 49 (1998) 230-43.

51 mGit. 1:4. The first part of this is an early tradition which was much enlarged in later rabbinic writings. This principle stands behind the wording of the divorce certificate which is represented by AD72.

52 Many writers are keen to emphasise this, e.g. Judith R. Wegner, Chattel or Person? The Status of Women in the Mishnah (Oxford: OUP, 1988), 75-76, 
21:10-11 was based on the law of the slave wife, and they found many parallels between the release of a woman from marriage and the release from slavery. ${ }^{53}$ The rules concerning release are similar and the wording of the two certificates was very similar. The emancipation certificate said: 'Lo, you are a free girl, you belong to yourself' and the only words which were necessary on a divorce certificate were 'Lo, you are permitted to (marry) any man' ${ }^{54}$ The rest of the divorce certificate is midrashic expansion. .55

This helps to explain why Paul uses words which are associated with slavery when he speaks about freedom from the marriage bond.

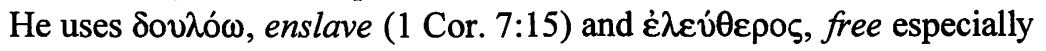
from slavery (1 Cor. 7:39; Rom. 7:3). It is probably also significant that he uses $\delta \varepsilon \dot{c} \omega$, bind, tie, fetter (1 Cor. 7:27, 39; Rom. 7:2), and $\lambda \dot{v} \omega$

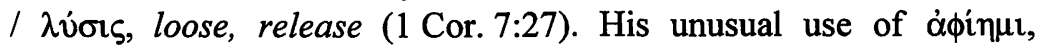
dismiss, release (1 Cor. 7:11-13) may also be related to this theme, because $\dot{\alpha} \phi i \eta \mu \mathrm{t}$ is often used with regard to release from slavery. ${ }^{56} \mathrm{He}$ also uses the imagery of slavery when he tells couples that their partner rules over their body so they owe each other their conjugal rights (1 Cor. 7:3-5).57

What does Paul mean when he uses this variety of language about being 'bound' or 'released'? Most of the time it is clear that he is speaking to those who are married about their marriage bond with

120-27; K. Kahana, The Theory of Marriage in Jewish Law (Leiden: E.J. Brill, 1966), 68, 90, 94. However, even Wegner and Kahana admit that a married woman's rights are far less than a divorced woman's-see Wegner, 137-38 and Kahana, 17-18.

53 See the talmudic discussions which follow mGit. 1:4. This is probably the origin the for way that the Talmud uses שר ש marriage contract-see especially bKidd. $13 b$ 'just as divorce completely frees her, so does death completely free her', and other references in Marcus Jastrow, $A$ Dictionary of the Targumim, the Talmud Babli and Yerushalmi, and the Midrashic Literature (New York: Pardes Publishing House, 1950), s.v.

${ }^{54}$ mGit. 9:3. 'To be permitted' (מותרת) is used as an abbreviation for 'permitted to marry' in mYeb. 1:2.

55 The phrases 'writ of release (ספר תרכין)' and 'bill of divorce (גט שבקין)' are translations of 'divorce certificate' (Dt. 24:1) in Targums Pseudo-Jonathan and Targum Neofiti respectively. 'To be permitted' in mGit. 9:3 is מותרת from , 'to loose, untie', which is also used in Targum Dt. 24:4. This is the equivalent of רשיא ' from רשי 'to have authority, permission' in AD 72.

56 Moulton \& Milligan, Vocabulary mentions the manumission in a Will

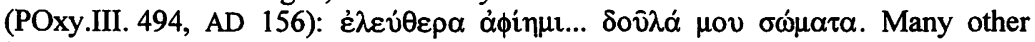
instances could be cited, especially in conjunction with $\dot{\varepsilon} \lambda \varepsilon v \dot{\theta \varepsilon p o \zeta . ~}$

57 This may be related to the use of $\dot{\varepsilon} \xi o v \sigma \alpha \dot{\alpha} \zeta \omega$ in Sir. 47:19 re Solomon's fall re women, 'You did bow your loins to women, and in your body you were brought into subjection.'- -suggested in M. Eugene Boring, Hellenistic Commentary to the New Testament (Nashville: Abingdon, 1995) ad loc. 
their partner (vv. 3-5, 11-13, 39). In verse 27 it is possible that he is speaking about release from a betrothal contract, ${ }^{58}$ and some have argued that he is even speaking about betrothal in verse 39.59 However, in both verses he uses $\delta \dot{\varepsilon} \omega$ which is also used with very similar terminology in Romans 7:2 where he certainly refers to marriage. Even so, many exegetes are uncertain about verse 27 and about verse 15 (which is the only place in this chapter where he uses $\left.\delta o v \lambda \omega^{\prime}\right) .{ }^{60}$ Normally one would assume that Paul is speaking in verse 15 and verse 27, as in all these other verses, about release from the marriage bond, but some exegetes are reluctant to do so because this implies that Paul was allowing remarriage.

Paul did not have to explicitly allow remarriage, and if he wished to forbid it for Christians, he would have to do so in very clear terms. ${ }^{61}$ Remarriage after divorce was a right enshrined in GraecoRoman and Jewish law. The establishment of this right was the main purpose of the Graeco-Roman divorce certificate ${ }^{62}$ and the sole purpose of the Jewish divorce certificate. ${ }^{63}$ As seen above, the Jewish concept of divorce was likened to release from slavery, not because marriage was restrictive, but because the marriage bond was taken so seriously. Paul is emphasising throughout 1 Corinthians 7 that the marriage bond is to be respected and not treated lightly, as in the Graeco-Roman culture, so he deliberately uses languages and images

${ }^{58} \mathrm{Keener}$ argues that it is impossible that this could refer to anything but a release from a marriage contract. He has some good points, but he probably states his case too strongly. See Craig S. Keener, ... And Marries Another: Divorce and Remarriage in the Teaching of the New Testament (Peabody MA: Hendrickson, 1991), 63.

59 See: Elliott, 'Paul's Teaching on Marriage', esp. pp. 221-22; Stephen Clark, Putting Asunder: Divorce and Remarriage in Biblical and Pastoral Perspective (Bridgend, Wales: Bryntirion, 1999), 167-72.

${ }^{60}$ Those who emphasise the difference between $\delta 00 \lambda{ }^{\circ} \omega$ and $\delta \varepsilon \dot{\omega} \omega$ include Roberts, 'The Meaning of Chorizo and Douloo'; William A. Heth, \& Gordon J. Wenham, Jesus and Divorce (London: Hodder \& Stoughton, 1984), 142; Fee, The First Epistle to the Corinthians, 302.

61 Some modern authors assume the opposite case, that if Paul wanted to allow remarriage he would have to state it clearly, e.g. Tomson, 'Paul and the Jewish Law', 120; Fee, The First Epistle to the Corinthians, 302-303; Pierre Dulau, 'The Pauline Privilege: Is It Promulgated in the First Epistle to the Corinthians?', $C B Q$ 13 (1951) 146-52, esp. p. 152.

62 It is arguable that the main purpose of the Graeco-Roman divorce certificate was to state that the dowry had been returned. This was certainly a very important aspect of the certificate, but the divorce certificate did not list the items returned, and its main function was as a sworn statement that there were no outstanding debts or issues relating to the marriage. In other words, both partners were legally free of obligations pertaining to the former marriage.

63 mGitt. 9:3. 
which have connotations of a slavery-type bond. It is therefore to be

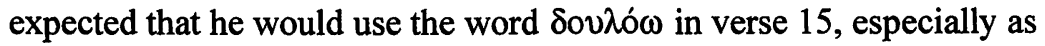
he is concerned, at this point, with a marriage where one partner has been forced into a situation they do not want.

In 1 Corinthians 7:15 Paul is dealing with the difficult case of the believer in a Graeco-Roman marriage to a non-believer who wishes to end the marriage. In practical terms there is nothing that the believer could do to save the marriage. They could not appeal to the teaching of the Gospel and urge their partner to stay (as Paul does in vv. 10-11) and nor could they appeal to the legal status of their marriage contract (as they could if they were Jews). All they can do is let their partner divorce them. ${ }^{64}$ But what then? Can they remarry? When Paul says they are 'no longer enslaved', any first century reader would understand him to mean that they can remarry, because they would think of the words in both Jewish and non-Jewish divorce certificates: 'You are free to marry'. If Paul had meant something else, he would have had to state this very clearly, in order to avoid being misunderstood by everyone who read his epistle.

The likely rabbinic response to this situation is found in a tradition in Mishnah:

A deed of divorce under duress is valid in Israel, but invalid if in a nonJewish court; but if the non-Jewish court pressurise him and say to him: 'Do whatever the Jewish Court tells you', then it is legal. (mGit. 9:8) (55 $^{2}$

The rabbis allowed a Jewish court to pressurise a man, even by beating him, but they did not enforce the decision of a non-Jewish court, though the problem was solved if the non-Jewish court referred him to the decision of a Jewish court.66 This meant that it was difficult for a Jewish woman to get a divorce certificate from a husband who walked out on her using the Greek law of divorce-by-separation. Without the divorce certificate she was not free to remarry. The same situation still pertains today. The women who are caught in this situation are called agunot or 'chained' women, because they are divorced but not free to remarry.

Paul's answer is pragmatic, as implied by the words 'God has called us to peace'. This is similar to the early rabbinic technical

\footnotetext{
${ }^{64}$ The use of $\chi \omega p i \zeta \omega$ in v. 15 is utterly unambiguous.

65 This cannot be dated any more exactly than sometime in the first two centuries AD.

${ }^{66}$ mGitt. 1:5; 9:8; mErak. 5:6. By Talmudic times there was a lively debate about whether or not to accept the rulings of Gentile courts if they had given the same ruling which the Jewish court would have given (bGit. 88b; yGit. 9:9).
} 
phrase 'for the sake of peace' which indicated a pragmatic solution to a difficult legal decision. ${ }^{67} \mathrm{He}$ does not give his reasoning, but it can probably be guessed. He presumably decided that when the nonbeliever walked out of the marriage, they became guilty of neglecting the material and emotional support of their partner. This formed grounds for divorce in biblical law, so they were entitled to a valid divorce. As far as Paul was concerned, Christians were obligated to provide emotional and material support just as Jews were, so presumably they were also allowed to claim a divorce on these grounds. Paul regarded the teaching of 'the Lord' to be that one should not walk out on a marriage as in the Hillelite or Graeco-Roman divorce-i.e. one should not end a marriage without biblical grounds. He did not regard adultery as the only ground for divorce any more than the Shammaites did or (in my opinion) Jesus did.

\section{Conclusions}

Virtually every facet of Paul's teaching about marriage and divorce in .1 Corinthians 7 can be illustrated by parallels in the Jewish and nonJewish marriage and divorce papyri. Paul is helping non-Jewish believers to cope with the Graeco-Roman custom of groundless divorce-by-separation. He reminds them that Jesus taught against a similar type of divorce within Judaism, and reminds them of their binding obligations within a marriage contract to provide emotional and material support for each other. He tells them that if their partner dies, or if they are divorced against their will, they are no longer bound by this contract and can remarry.

The only facet which is not paralleled by the papyri is Paul's combination of equality and security of both men and women in marriage. Graeco-Roman marriages gave equality to men and women, because either partner could opt out of a marriage at any point, but there was little security. Jewish marriages gave total security to the man, so long as he did not give his wife grounds for divorce, but the woman had no security and could be given a divorce certificate at any

67 For example the non-Jewish poor were not strictly allowed to take the gleanings, but they were allowed 'for the sake of peace', and mentally defective people were not punished for minor theft 'for the sake of peace' (mGit. 5:8). Fee regarded it as meaning 'in order to make a good impression on Gentiles' (First Epistle to the Corinthians, ad loc.), but I have shown elsewhere that it was rabbinic legal terminology for what we might now call 'pragmatism' (Instone-Brewer, Techniques, 21, 37, 82, 144-45). 
time. Christian marriages had the security of a pre-Hillelite Jewish contract, which forbade divorce except on the biblical grounds of emotional neglect, physical neglect or adultery. Christian marriages also gave equal rights to men and women who could both gain a divorce for any of the biblical grounds without the one-sided right of the husband who was the only one who could validate the divorce by writing out the certificate. ${ }^{68}$

Paul has a positive approach to marriage throughout. Although he warns against starting a family during a time of famine, ${ }^{69}$ he strongly affirms the goodness of marriage and he denies the idea that it is sinful. He emphasises throughout that a marriage is binding and that believers should do everything within their power to avoid the circumstances which lead to a divorce, such as separating or not fulfilling their marital obligations. He leads believers from a world of Graeco-Roman morals, through to a world of Jewish morals, and beyond to a world of Christian morals.

68 Even in pre-Hillelite marriage contracts, a woman could not get a divorce on the grounds of adultery because Jewish law allowed polygamy, so marriage did not commit a Jewish husband to sexual faithfulness. Jesus taught monogamy, which removed this inequality - see my 'Jesus' OT Basis for Monogamy'.

${ }^{69}$ As seen in the previous paper, p. 114. 